\title{
Practice of Applied Talent Training in Innovation and Entrepreneurship Education in Colleges and Universities
}

\author{
Boru Yang and Wen Zhou \\ Yunnan College of Foreign Affairs \& Foreign Language Yang Lin 651700
}

Keywords: Applied talent; Innovation and entrepreneurship; Practice

\begin{abstract}
Many colleges and universities in China today are positioning innovative and entrepreneurial talents to cultivate applied talents. But how to achieve this goal is a matter of opinion. This paper is based on effectively solving this problem. From an accurate understanding of innovation and entrepreneurship education, the full implementation of innovation and entrepreneurship practice teaching, the practice of teaching throughout the entire process of innovation and entrepreneurship teaching, infiltration in all aspects of teaching, is to achieve effective training of applied talents target approach. It is hoped that this study will help the practice of innovation and entrepreneurship education and cultivate more innovative and entrepreneurial talents.
\end{abstract}

\section{Introduction}

As we all know, at the end of the last century, with the popularization of higher education in China and the diversification of the school system, with the release and implementation of the Party Central Committee's strategy of "powerful country with talented people", the voice of teaching reform and innovation was quite spectacular. The practice teaching is also in the light of the wave of reform, which is of general concern to the higher education sector, especially the institutions of higher learning that aim at training applied talents. The Ministry of education has put forward a series of relevant opinions at the right time, emphasizing: "vigorously strengthening practical teaching and improving the practical ability of college students. Colleges and universities should strengthen the awareness of practical education, distinguish the requirements of different disciplines for practical teaching, rationally formulate practical teaching plans, and improve the practice teaching system."

However, we find that, on the one hand, many colleges and universities in the promotion of practical teaching activities have increased the strength of the system, created a variety of new forms of teaching organizations and methods, and achieved certain results. On the other hand, due to the differences between the connotation and denotation of practical teaching, the promotion of practical teaching is confronted with bottlenecks, and the impact and effectiveness are obviously limited. This paper studies the cultivation of innovative and entrepreneurial talents and applied talents, hoping to help practical education.

\section{Innovation and Entrepreneurship Education and the Training of Applied Talents}

Cultivating high-quality personnel with professional background, critical thinking ability and creativity is in line with the requirements of application-oriented education. Integrated innovation of technology is an essential quality and ability for application-oriented undergraduates. At the same time, based on the social development and economic transformation of high-quality applied talents training objectives, innovation and entrepreneurship education is the proper meaning of college education, not out of the traditional teaching system, it should be throughout the professional education process, and promote the reform of teaching methods and the exploration and practice of personnel training models. The ultimate goal of implementing innovation and entrepreneurship education lies in cultivating talents that can "use", that is, to cultivate creative talents with entrepreneurial spirit that can adapt to the needs of national industrial development and can actively serve the economic transformation and development. 
Innovation and entrepreneurship education are two inseparable educational concepts. Innovation and entrepreneurship education should be a unified system. The core is to cultivate college students' sense of innovation, entrepreneurial spirit and innovative entrepreneurial ability. Among them, for students, innovation is the starting point and fulcrum, while entrepreneurship is the expression of target output and value, that is, innovation is committed to entrepreneurship and entrepreneurship based on innovation. Employment based on profession, is the employment orientation of college students, and entrepreneurship based on innovative achievements is the high quality entrepreneurial practice of undergraduate talents. Undergraduate education in innovation and entrepreneurship can effectively improve college students' ability to innovate and innovation-based entrepreneurship.

\section{The Basic Principles of College Students' Innovation and Entrepreneurship Education}

Directional Principle. The innovation and entrepreneurship education carried out in colleges and universities must adhere to the direction of running a socialist university. It must be in line with China's major strategy of building an innovative country, cultivate a large number of innovative and entrepreneurial talents with innovative spirit and practical ability, and focus on encouraging and guiding college students embark on the road of self-development, promote employment through entrepreneurship, and promote the smooth development of the "double innovation" campaign.

Broad-spectrum Principle. The innovation and entrepreneurship education carried out in colleges and universities should be oriented toward all students. We should integrate innovation and entrepreneurship education into the whole process of personnel training, and strive to enhance and improve the students' innovation consciousness, entrepreneurial spirit and entrepreneurial ability. Innovation and entrepreneurship education should be integrated with the career development and employment guidance of college students. It must be linked with the full implementation of quality education and focus on "effectiveness" so as to realize "innovation leads entrepreneurship and entrepreneurship drives employment".

The Principle of Coordination. The general goal of innovation and entrepreneurship education in colleges and universities is to cultivate college students' quality of innovation and entrepreneurship. To achieve this goal requires coordination among multiple entities within the school, national policies, social environment, enterprises and institutions, implementation of the colleges and universities innovation capability improvement plan, science and education coordinated education plan to build a long-term mechanism for scientific research to feed back innovation and entrepreneurship education, and form a harmonious resonance.

The Principle of Specialization. The innovation and entrepreneurship education carried out in colleges and universities should be based on the orientation of running schools, consolidate the characteristics of schools, and enable schools to continue to cast the features of "entrepreneurial" schools based on the traditional mission of teaching and research. We must base ourselves on student-centeredness and achieve the education of "stratification" and "differentiation", so that the students can not only master the "learning" and "skill" of innovation and entrepreneurship, but also become the people with firm spirit of pioneering, different professional characteristics and different ways of thinking.

\section{University Innovation and Entrepreneurship Status and Problems}

According to survey data from college students' information consultation and employment guidance centers nationwide covering nearly 10,000 college students, $27.12 \%$ of college students have a strong desire to start a business, and $58.03 \%$ have a willingness to start a business, reflecting that college students generally have innovation and entrepreneurship willingness.

At what time of entrepreneurship, the respondents chose to work for a period of time and accounted for $52.8 \%$ of the total. They chose $28.8 \%$ as long as they had the willingness to start a business, and $14 \%$ chose to start their own business when they graduated. $10 \%$ of students choose to start a business during school. The survey also revealed that more than three-fourths of the students hope that the school will carry out entrepreneurial education, and that entrepreneurship 
education is very necessary to account for $31.96 \%$ and $44.01 \%$, altogether accounting for $75.97 \%$, accounting for $15.1 \%$ of discretionary, Only $2.85 \%$ were deemed unnecessary.

This series of data shows that with the introduction of a series of preferential policies to promote the employment of college graduates in the country, there has been some change in the employment concept of graduates. Judging from the current situation, there will be more and more college students who start their own businesses in society, and they may even become the mainstream of employment in the future, becoming the first choice for college students after graduation.

Because of their age, experience, and knowledge, college students' own business ventures cannot overcome barriers in knowledge, experience, mentality, technology, and capital for several years. In the actual investigation, there are several major problems in the self-employment of college students.

The Enthusiasm is High, but the Actual Proportion of Entrepreneurship is Low. Since college students come into contact with college students entrepreneurship, the passion for entrepreneurship of college students in our country has gradually increased, and the speed and number of entrepreneurs have increased rapidly. Chinese college students have a strong desire to start a business, but the proportion of actual participation in entrepreneurship is still very low.

Low Conversion rate of Science and Technology. Among the college students who start their own businesses in the country, many students are engaged in such industries as tutoring, retailing, and service industries. Even entrepreneurs involving the Internet are concentrated in websites that do not require product design, development, and production.

The Social Cultural Foundation of Entrepreneurship is Weak. Undergraduate entrepreneurship in China lacks the social cultural atmosphere to support and nurture. Undergraduate entrepreneurship has not yet won the full support and recognition of society and family. There are not many parents who clearly encourage college students to start their own businesses. No matter whether they are college students who promote entrepreneurship to the society or entrepreneurs who promote entrepreneurship to colleges and universities, the atmosphere of public opinion is not strong. Objectively speaking, the path of college students' entrepreneurship is characterized by originality, reality, diversity, arduous and risk.

The road to entrepreneurship is its own, and there is only one path that is most suitable for you. Students can stick to their own stable development knowledge systems without sticking to traditional concepts and keeping their old ones. They are good at adopting the correct ideas, assumptions, methods, and programs based on the laws of changing things, and they will find a way that suits them. Therefore, with diversity. Entrepreneurship is different from employment. Choosing a entrepreneurship means choosing a challenge. This road of entrepreneurship is by no means a straight, broad and unobstructed road for college students, so it is arduous. There is no effective method to set up a business. It is impossible to succeed every time. It is impossible for everyone to succeed. Sometimes it may be unproductive and sometimes cause significant losses. Therefore, it is very risky.

\section{Take more Measures to Support the Innovation and Entrepreneurship of Applied Education}

System Security, Planning Innovation and Entrepreneurship Education. The school adheres to the people-oriented concept of innovation and entrepreneurship education. It focuses on stimulating students' interest and teacher enthusiasm, and establishes system documents such as organization management, funding input, platform resources, team building, and course credit certification. At the same time, the "Changshu Institute of Technology Innovation and Entrepreneurship Education Steering Committee for College Students" was established to build a collaborative training system for college students' innovation and entrepreneurship practices. We will vigorously promote a new model of application-oriented personnel training with innovation and entrepreneurship awareness and ability as the core. The effectiveness of innovation and entrepreneurship education for college students will become more apparent, and the push for the cultivation of applied talents will increase.

Conditional Support to Strengthen the Construction of the Platform Team. Through "selecting, training, citing, recruiting, and hanging" and other ways to enrich the instructive team of 
innovators and entrepreneurs in and out of the school, through the scientific research and nurturing education, the discipline promotes training, and the science promotes the formation of a diverse structure of instructors. Nearly 100 instructors were selected in the school. Each year, teachers were organized to participate in related disciplines competition training, entrepreneurship simulation training, sending teachers to the enterprise to experience entrepreneurship, employing industry and business success, and giving guidance on college students' innovation and entrepreneurship activities.

Project Promotion, Construction of Cultivation System and Implementation of Brand Management. To build a four-level education system for college students' innovation and entrepreneurship education at the national, provincial, school, and college levels. School-level projects are generated from the college-level projects, provincial-level projects are selected from school-level projects, national-level projects are selected from provincial-level projects, and national-level project leaders, provincial-level projects, and school-level projects are supported. The four-level training and practice system for four-level innovation and entrepreneurship education projects based on college-level projects. In terms of project selection, it focuses on the process of innovation training and practice for undergraduates, and pays attention to three dimensions, namely student participation, professional interest promotion and professional skill proficiency. The project selection is mainly based on pre-research projects, sub-topics, and development topics for teachers' scientific research. The comprehensive and design training programs of the open laboratory, the engineering practice projects in the school-enterprise cooperation, and the students' self-designed projects based on professional production and invention are the main topics.

Curriculum Improvement, Promote Innovation and Entrepreneurship Education into Training Programs. Encourage the development of innovative courses based on subject competitions and innovation and entrepreneurship projects, and set up student innovation credits. Combining professional construction and teaching reform, we will select projects or groups of projects that are helpful to the cultivation of innovation and entrepreneurship from teachers' scientific research achievements, various discipline competitions, and innovative training programs, and conduct content migration, refinement, and regulation, and internalize them into one. A series of professional innovative courses and design and research experimental training projects cultivate students' ability to creatively solve complex practical problems.

Leading the Culture and Unifying the Value Orientation of Innovation and Entrepreneurship Education. Through the construction of the value pursuit of innovation and entrepreneurship, the thinking mode of innovation and entrepreneurship, the traditional atmosphere of innovation and entrepreneurship, and the psychological atmosphere of innovation and entrepreneurship, the cultural ecology of the students' innovation consciousness, the spirit of innovation and entrepreneurship, and the development of innovation and Entrepreneurship are encouraged, and the teaching of the creative and entrepreneurial culture environment of the campus is brought into full play the function of guidance and motivation. We regularly organize college students' science and technology festival, discipline competition propaganda month and college students' innovative and entrepreneurial achievement exhibition to show the outstanding achievements of the students' innovation and entrepreneurship, and guide the students to form the value pursuit and interest orientation of the innovation and entrepreneurship education as "a new way of learning".

\section{Summary}

As we all know, the problem of talent training in China's higher education deviating from the demand for talents has aroused widespread concern and has been widely questioned. To overcome the drawbacks of university teaching effect and the needs of talents in economic society, we should develop applied education talents. This paper attempts to promote effective teaching with the full implementation of practical teaching, that is, effective teaching, effective learning, and the cultivation of effective applied talents. So as to overcome the disadvantages of disconnecting college teaching effectiveness from the needs of economic and social talents. 


\section{Reference}

[1] Min G E, Chen X P. Practice and Exploration on the Training of Economic Management Talents with "Innovation and Entrepreneurship" in Local Colleges and Universities[J]. Value Engineering, 2012.

[2] Yang C, Xie Y, Cai Y, et al. Analysis of Intellectual Property Training System Served Innovation and Entrepreneurship Students in College[J]. Forum on Science \& Technology in China, 2013, 17(3):9-36.

[3] Shi-Tong Y E, Wan Z P, Ren Z J. An Exploration of College Innovation and Entrepreneurship Education: An Integration of Quality, Training, Research and Application[J]. Journal of Ningbo University, 2014.

[4] Wang Q, Wu J. Thoughts on Integrating Innovation and Entrepreneurship Education into the Whole Process of Talent Training[C]// International Conference on Management, Computer and Education Informatization. 2015:1-8.

[5] Wen J, Wang H. Research on the Construction of a Psychological Training System for College Students' Innovation and Entrepreneurship[J]. Science Education Article Collects, 2015.

[6] Ge C. Elementary Discussion on Achievement Transformation and Extension for Training Programs of Innovation and Entrepreneurship for Undergraduates[J]. Science Education Article Collects, 2015.

[7] Mao-Lin X U. An Analysis of Training Strategies for College Students' Innovation and Entrepreneurship Ability[J]. Journal of Zhangjiakou Vocational \& Technical College, 2016.

[8] Zhang L P. Research on the Training Development of Farmer Innovation and Entrepreneurship in Higher Vocational Colleges[J]. Journal of Hubei Correspondence University, 2016.

[9] An-Ping D U. Literature Retrieval Instruction Model Based on Undergraduate Training for Innovation and Entrepreneurship[J]. Library Research, 2016.

[10] Liu X P, Zhang X W. Research on the innovation and entrepreneurship personnel training mode in science and engineering colleges[J]. Journal of Hebei University of Engineering, 2016.

[11] Chen Z, Huang Y. Study on the Training of Design Students' Innovation and Entrepreneurship Ability from the "Design Management lab" Course of Politecnico di Milano[J]. Furniture \& Interior Design, 2016.

[12] Jia S, Chu Y, Chen X, et al. Implementation and Management of Undergraduate Innovation and Entrepreneurship Training Program for Local Universities[J]. Research \& Exploration in Laboratory, 2017.

[13]Zhang Q. Reconstruction of practical ability training system in colleges and universities guided by innovation and entrepreneurship[J]. Experimental Technology \& Management, 2017.

[14]Lin G. The Reform of Training Mode of Marketing Professional Talents under the Perspective of Innovation and Entrepreneurship[J]. Journal of Hefei Normal University, 2017. 